\title{
The Effect of the Heavy Metal Mercury (Hg) Concentration on the Growth Rate of Pilsbryoconcha spp Mussel
}

\author{
Afreni Hamidah ${ }^{1, *}$ Evita Anggereini ${ }^{2}$ \\ ${ }^{12}$ biology education study programme, faculty of teacher training and science education, Jambi University \\ *Corresponding author. Email: rozakhfiira@ gmail.com
}

\begin{abstract}
The purpose of this study was to determine the effect of heavy metal mercury $(\mathrm{Hg})$ concentration on the growth rate of Pilsbryoconcha spp mussels and to compare the growth rates of Pilsbryoconcha spp mussels exposed to mercury at different concentrations. The type of research used is quantitative research with experimental methods. The study used a completely randomized design with 3 treatments and 6 repetitions. The treatments were different levels of mercury, namely P0, P1 and P2 (0, 0.5 and $1 \mathrm{ppm})$. Data were analyzed for variations using ANOVA. If there is a significant effect, then proceed with the Duncan Multiple Range Test (DMRT) with $\alpha 5 \%$. The length growth rates in treatment P0, $\mathrm{P} 1$ and $\mathrm{P} 2(0,0.5$ and $1 \mathrm{ppm} \mathrm{Hg})$ ranged from 0.12 to $0.22 ; 0.08-0.09$ and $0.03-0.1 \mathrm{~cm} /$ observation or there is a decrease in the length growth rate from the control treatment of $0.16 \mathrm{~cm} /$ day to only $0.006 \mathrm{~cm} /$ day at P1 treatment, and the more decrease at P2 $0.002 \mathrm{~cm} /$ day. The weight gain along observation is ranged from 0.071-0.349 $\mathrm{g}(\mathrm{P} 0), 0.031-0.077$ at P1, and decreased at $\mathrm{P} 2$ reaching -0.03 to $0.006 \mathrm{~g}$. The average daily length of mussel was $0.012 ; 0.006$ and $0.004 \mathrm{~cm} / \mathrm{day}$ in $\mathrm{P} 0, \mathrm{P} 1$ and $\mathrm{P} 2$ respectively.The average daily weight rate was $0.052 \mathrm{~g} /$ day in the $\mathrm{P} 1$ and $-0.068 \mathrm{~g} /$ day in $\mathrm{P} 2$, while the control (P0) was $0.158 \mathrm{~g} /$ day. The average relative length of mussels was $0.02,0.01$ and $0.007 \mathrm{~cm}$, whereas the average weight growth of mussel was $0.081 ; 0.024$ and $-0.035 \mathrm{~g}$. Lengtht and weight growth rate of mussels in P0 and P1 treatment are not different significantly, but significantly difference in $\mathrm{P} 2$ treatment. This shows that mercury is very dangerous for the life of Pilsbryoconcha spp and can reduce the weight and inhibit length growth mussel during maintenance.
\end{abstract}

Keywords: Mercury, Growth rate, Pilsbryoconcha spp Mussel.

\section{INTRODUCTION}

Pilsbriyoconcha spp are a type of mussels belonging to the Unionidae family, the Bivalvian class of the Mollusca phylum. These mussels are widely consumed by people in Jambi Province as a source of animal protein which is cheap and easy to obtain, a source of feed for livestock and fish, and can be used as a bioindicator of environmental pollution. Similar mussels are also found in the Ogan Komering llir River and the Enim River in South Sumatra, Sipin Lake, and the others river and have been studied with respect to reproductive aspects and cultivation [1][2].

Mercury is one of the heavy metals that are harmful to organisms. One of the heavy metals that can pollute rivers in several districts in Jambi Province is Mercury (Hg). BPLHD (2015) [3] states that gold mining in Jambi
Province is taking place intensively in three districts, namely Merangin, Bungo, and Sarolangun. Mercury is often used to bind gold core in unlicensed traditional gold mining (known as PETI) through the amalgamation process. The amalgamation technique has the potential to cause pollution in the environment, this is due to the accumulation of mercury in the ecosystem through the food chain. Mercury pollution in the environment can cause bioaccumulation in the food pyramid, starting from plants, aquatic animals, fish, and eventually accumulating in humans [4]. Mercury that accumulates in the environment will be oxidized to organic mercury called methyl mercury $(\mathrm{MeHg})$ by biological systems. $\mathrm{MeHg}$ can penetrate the membranes of living things and cause poisoning in humans [5] [6]. Some research results show the successful use of freshwater mussels as a biofilter. Mussel is a filter feeder animal and is able to filter out particles of size between 0.1-50 $\mu \mathrm{m}$ from water 
bodies, then at particle sizes $>4.0$ it can filter up to $100 \%$ [7]. Anodonta mussels are able to filter water up to $401 /$ day and can extract colloidal organic matter, either suspended or particles, and can reduce the organic matter content in the waters by an average of $99.5 \%$. According to Prihartini [8][9], another type of mussels, Pilsbryoconcha spp can help in water purification efforts, utilizing food scraps that are not eaten by fish, as a biofilter because it has high survival and in large quantities it can be used to overcome water pollution due to pollutants including metals. weight.Some research results show the successful use of freshwater mussels as a biofilter and bioaccumulator of heavy metals including mercury, but little is known about how it affects the growth rate of Pilsbryoconcha spp mussels. The purpose of this study was to determine the effect of the concentration of heavy metal mercury $(\mathrm{Hg})$ on the growth rate of Pilsbryoconcha spp mussels and to compare the growth rates of Pilsbryoconcha spp mussels exposed to heavy metal mercury at different concentrations.

\section{METHODS}

\subsection{Research Location and Time}

The research was carried out in the Integrated Biology Education Laboratory of Jambi University from June to August 2020.

\subsection{Research Design}

The type of research used is quantitative research with experimental methods. The study used a completely randomized design (CRD) with 3 treatments and 6 repetitions in order to obtain 18 experimental units. The treatments were different levels of mercury, namely 0 , 0.5 and $1 \mathrm{ppm}$.

$\mathrm{PO}=$ Aquarium with $0 \mathrm{ppm}$ mercury concentration with 15 Pilsbryoconcha spp (control)

$\mathrm{P} 1$ = Aquarium with $0.5 \mathrm{ppm} \mathrm{Hg}$ concentration +15 Pilsbryoconcha spp
$\mathrm{P} 2=$ Aquarium with $1 \mathrm{ppm} \mathrm{Hg}$ concentration +15 Pilsbryoconcha spp

\subsection{Data Collection Techniques}

Growth measurements were carried out by measuring the increase in shell size every 2 weeks for 2 months of rearing exposed to different levels of $\mathrm{Hg}$. The parameters of the study included daily growth rate and relative growth rate mussels.

\subsection{Data Analysis}

Data were analyzed for variations using ANOVA to see the effect between treatments. If there is a significant effect, then proceed with the Duncan Multipe Range Test (DMRT) with $\alpha 5 \%$.

\subsection{Research Procedures}

The research began with the initial weighing and measurement of the mussels and the preparation of a mercury solution with various levels. Furthermore, the mussels was acclimatized for 1 week and the test animals used were $7-9 \mathrm{~cm}$ in size. Maintenance was carried out for 2 months and measurements were made of length and weight of mussels in every 2 weeks.

\section{RESULT}

Growth is the change in size, weight, length and volume in the rate of increasing time. There are two types of growth, namely absolute growth and relative growth. Absolute growth is the average measure at a certain age, while relative growth is the length or weight achieved in a certain period of time related to the initial length or weight of that period. Growth observations on Pilsbyroconcha spp mussel were carried out for 2 months of maintenance which was carried out every 2 weeks. The growth rate of Pilsbyroconca spp mussels due to exposure to heavy metal mercury $(\mathrm{Hg})$ at 3 different concentrations obtained data as in Tables 1-3.

Table 1. Result of Morphometric Measurement Every 2 Weeks Of Observation

\begin{tabular}{|c|c|c|c|c|c|c|}
\hline \multirow{2}{*}{$\begin{array}{c}\text { Observation } \\
\text { to }\end{array}$} & \multicolumn{3}{|c|}{ Length (cm/2 weeks) } & \multicolumn{3}{c|}{ Weight (gr/2 weeks) } \\
\cline { 2 - 7 } & P0 & P1 & P2 & $\mathbf{0}$ & $\mathbf{0 , 5}$ & $\mathbf{1}$ \\
\hline I & 8,30 & 8,36 & 8,11 & 27,31 & 29,63 & 26,75 \\
\hline II & 8,30 & 8,36 & 8,12 & 27,61 & 29,74 & 26,71 \\
\hline III & 8,40 & 8,39 & 8,13 & 27,98 & 29,96 & 26,47 \\
\hline IV & 8,41 & 8,41 & 8,14 & 29,17 & 30,20 & 26,06 \\
\hline V & 8,46 & 8,44 & 8,16 & 29,54 & 30,34 & 25,81 \\
\hline Mean & $\mathbf{8 , 3 7}$ & $\mathbf{8 , 3 9}$ & $\mathbf{8 , 1 3}$ & $\mathbf{2 8 , 3 2}$ & $\mathbf{2 9 , 9 7}$ & $\mathbf{2 6 , 3 6}$ \\
\hline
\end{tabular}

The results of measurement of length growth of mussel for 2 months from observations 1 to 5 can be seen in Table 2. The length growth rates in treatment $\mathrm{P} 0, \mathrm{P} 1$ and $\mathrm{P} 2(0,0.5$ and $1 \mathrm{ppm} \mathrm{Hg})$ ranged from 0.12 to $0.22 ; 0.08$ 0.09 and $0.03-0.1 \mathrm{~cm} /$ observation or there is a decrease in the length growth rate from the control treatment of $0.16 \mathrm{~cm} /$ day to only $0.006 \mathrm{~cm} /$ day at $\mathrm{P} 1$ treatment $(0.5$ $\mathrm{ppm} \mathrm{Hg}$ ), and the more significant decrease at $1 \mathrm{ppm} \mathrm{Hg}$ of $0.002 \mathrm{~cm} /$ day. 
Table 2. Average Length Growth of Pilsbryoconcha spp. Mussel

\begin{tabular}{|c|c|c|c|}
\hline Repetition & P0 & P1 & P2 \\
\hline 1 & 8,23 & 8,37 & 7,92 \\
\hline 2 & 8,34 & 8,41 & 8,00 \\
\hline 3 & 8,21 & 8,43 & 8,05 \\
\hline 4 & 8,35 & 8,36 & 8,19 \\
\hline 5 & 8,50 & 8,37 & 8,19 \\
\hline 6 & 8,60 & 8,39 & 8,45 \\
\hline Mean & $\mathbf{8 , 3 7}^{\mathbf{a}}$ & $\mathbf{8 , 3 8}^{\mathbf{a}}$ & $\mathbf{8 , 1 3}^{\mathbf{b}}$ \\
\hline
\end{tabular}

Note:Data that are not followed by the same letter represent significant differences effect at the $\mathrm{p}>0.05$ level

Table 3 shows the weight growth of the mussel in each aquarium with 3 treatments for 2 months of maintenance. The weight gain along observation with the level of mercury is ranged from $0.071-0.349 \mathrm{~g}(\mathrm{P} 0=0$ ppm), 0.031-0.077 at $\mathrm{P} 1(0.5 \mathrm{ppm} \mathrm{Hg})$ and decreased at P2 (1 ppm $\mathrm{Hg}$ ) reaching -0.03 to 0.006 g.The results showed that mercury affected the length and weight growth rate mussels. Lengtht and weight growth rate of mussels in P0 and P1 treatment are not different significantly, but significantly difference in P2 treatment than the others.
Table 3. Average Weight Growth Pilsbryoconcha spp. Mussel

\begin{tabular}{|c|c|c|c|}
\hline Repetition & P0 & P1 & P2 \\
\hline 1 & 25,87 & 29,12 & 26,35 \\
\hline 2 & 26,59 & 29,32 & 25,49 \\
\hline 3 & 26,40 & 29,64 & 26,37 \\
\hline 4 & 28,62 & 30,19 & 26,18 \\
\hline 5 & 31,65 & 30,37 & 25,54 \\
\hline 6 & 30,80 & 31,19 & 28,22 \\
\hline Mean & $\mathbf{2 8 , 3 2}^{\mathbf{a}}$ & $\mathbf{2 9 , 9 7}^{\mathbf{a}}$ & $\mathbf{2 6 , 3 6}^{\mathbf{b}}$ \\
\hline
\end{tabular}

Note: Data that are not followed by the same letter represent significant differences effect at the $p>0.05$ level.

The average daily length of mussel was 0.012; 0.006 and $0.004 \mathrm{~cm} /$ day in P0, P1 and P2 respectively. The average daily weight rate was $0.052 \mathrm{~g} /$ day in the P1 treatment $(0.5 \mathrm{ppm} \mathrm{Hg})$ and $-0.068 \mathrm{~g} /$ day in $\mathrm{P} 2(1 \mathrm{ppm}$ $\mathrm{Hg}$ ), while the control ( $\mathrm{P} 0)$ was $0.158 \mathrm{~g} /$ day. The results of further analysis showed that the increase in daily weight and length of Pilsbryoconcha spp between mercury levels was very significant difference, especially between $\mathrm{P} 2$ treatment with the addition of $1 \mathrm{ppm}$ from the other treatment, $\mathrm{P} 0$ and $\mathrm{P} 1$. This shows that mercury is very dangerous for the life of Pilsbryoconcha spp and prolonged mercury exposure can reduce the growth rate of weight mussel during maintenance.

Table 4. Daily Growth Rate of Mussel

\begin{tabular}{|c|c|c|c|c|c|c|}
\hline \multirow{2}{*}{$\begin{array}{c}\text { Repetition } \\
\text { to }\end{array}$} & \multicolumn{3}{|c|}{ Length (cm) } & \multicolumn{3}{c|}{ Weight (gr) } \\
\cline { 2 - 7 } & $\begin{array}{c}\mathbf{0} \text { ppm } \\
\text { Hg (P0) }\end{array}$ & $\begin{array}{c}\mathbf{0 , 5} \text { ppm } \\
\text { Hg (P1) }\end{array}$ & $\begin{array}{c}\text { 1 ppm } \\
\text { Hg (P2) }\end{array}$ & $\begin{array}{c}\mathbf{0} \text { ppm Hg } \\
\text { (P0) }\end{array}$ & $\begin{array}{c}\mathbf{0 , 5} \text { ppm } \\
\text { Hg (P1) }\end{array}$ & $\begin{array}{c}\text { 1 ppm } \\
\text { Hg (P2) }\end{array}$ \\
\hline 1 & 0,016 & 0,006 & 0,004 & 0,137 & 0,047 & 0,006 \\
\hline 2 & 0,009 & 0,006 & 0,003 & 0,094 & 0,062 & $-0,14$ \\
\hline 3 & 0,016 & 0,006 & 0,007 & 0,071 & 0,077 & $-0,03$ \\
\hline 4 & 0,010 & 0,006 & 0,002 & 0,174 & 0,048 & $-0,08$ \\
\hline 5 & 0,009 & 0,006 & 0,004 & 0,349 & 0,039 & $-0,09$ \\
\hline 6 & 0,012 & 0,006 & 0,003 & 0,131 & 0,031 & $-0,07$ \\
\hline Total & $\mathbf{0 , 0 7 2}$ & $\mathbf{0 , 0 3 6}$ & $\mathbf{0 , 0 2 3}$ & $\mathbf{0 , 9 5 0}$ & $\mathbf{0 , 3 1 0}$ & $\mathbf{- 0 , 4 0 4}$ \\
\hline Mean & $\mathbf{0 , 0 1 2}$ & $\mathbf{0 , 0 0 6}$ & $\mathbf{0 , 0 0 4}$ & $\mathbf{0 , 1 5 8}$ & $\mathbf{0 , 0 5 2}$ & $\mathbf{- 0 , 0 6 8}$ \\
\hline
\end{tabular}

The average relative length and weight growth in each treatment ( $\mathrm{P} 0, \mathrm{P} 1$ and $\mathrm{P} 2)$ shows in Table 5. The average relative length rate of mussels were 0.02,0.01 and 0.007 , whereas the average weight growth of mussel were $0.081 ; 0.024$ and $-0.035 \mathrm{~g} /$ observation. The relative weight growth at $1 \mathrm{ppm}$ with $0.5 \mathrm{ppm}$ of mercury or between P1 and P2 was not different, but very different when compared to control.

Table 5. Relative Growth of Mussel

\begin{tabular}{|c|c|c|c|c|c|c|}
\hline \multirow{2}{*}{$\begin{array}{c}\text { Repetition } \\
\text { to }\end{array}$} & \multicolumn{3}{|c|}{ Length (cm) } & \multicolumn{3}{c|}{ Weight (gr) } \\
\cline { 2 - 7 } & Control & $\begin{array}{c}\mathbf{0 , 5} \\
\text { ppm }\end{array}$ & $\begin{array}{c}\mathbf{1} \\
\text { ppm }\end{array}$ & Control & $\begin{array}{c}\mathbf{0 , 5} \\
\text { ppm }\end{array}$ & $\mathbf{1} \mathbf{p p m}$ \\
\hline 1 & 0,027 & 0,010 & 0,006 & 0,076 & 0,022 & 0,003 \\
\hline 2 & 0,014 & 0,009 & 0,005 & 0,050 & 0,030 & $-0,073$ \\
\hline 3 & 0,028 & 0,010 & 0,013 & 0,038 & 0,037 & $-0,015$ \\
\hline 4 & 0,016 & 0,009 & 0,004 & 0,090 & 0,022 & $-0,043$ \\
\hline 5 & 0,014 & 0,010 & 0,006 & 0,170 & 0,018 & $-0,048$ \\
\hline 6 & 0,019 & 0,009 & 0,005 & 0,061 & 0,014 & $-0,033$ \\
\hline Total & $\mathbf{0 , 1 1 8}$ & $\mathbf{0 , 0 5 7}$ & $\mathbf{0 , 0 3 9}$ & $\mathbf{0 , 4 8 5}$ & $\mathbf{0 , 1 4 3}$ & $\mathbf{- 0 , 2 0 9}$ \\
\hline Mean & $\mathbf{0 , 0 2 0}$ & $\mathbf{0 , 0 1 0}$ & $\mathbf{0 , 0 0 7}$ & $\mathbf{0 , 0 8 1}$ & $\mathbf{0 , 0 2 4}$ & $\mathbf{- 0 , 0 3 5}$ \\
\hline
\end{tabular}




\section{DISCUSSSION}

Heavy metal mercury that enters the aquatic environment will experience deposition, dilution and disperse [10][11][12]. Mercury waste that is produced from the gold management process will enter the river and marine ecosystems and can sink into the bottom of the water which is then concentrated in sediments [13]. This waste not only settles in the sediment, but part of the waste will enter and accumulate into the tissues of the biota in river waters, including bivalves. Based on the table, it can be seen that the higher the level of mercury application, the slower the growth of mussels. This means that mercury can disrupt the work of the kidneys and nerves, digestive and respiratory systems. Water containing the heavy metal mercury enters the respiratory and digestive systems. This results in disruption of the organ system and inhibition of the absorption of food juices so that growth, both absolute and relative growth, becomes slow. In line with the results of research by Pratiwi and Ariesyady [14], the effects of mercury poisoning can cause kidney and central nervous system disorders, memory loss, tremors, sensory disturbances and permanent damage to the brain and kidneys. Another effect that can be caused is in the form of disorders of the digestive and respiratory systems.

Pilsbryoconcha spp is an animal that gets food by sucking water without selection so that it is classified as a filter feeder. Water enters the mantle through the bottom of the inhalant siphon and continues to flow toward the gills and out again through the top of the inhalant siphon. The food particles will join the water in the mucus, before being sent to the mouth. In this section the food particles will be selected. Small particles will pass into the esophagus, then into the intestine, while large particles will come out again with the water through the inhalant siphon [15][16]. The slow growth rate of mussel is caused by the entry of heavy metals into the shells in line with the absorption of water and nutrients through the filter feeder process. According to Puspasari [17] and Suryono [18], there are two kinds of mechanisms for the entry of heavy metals into an organism's body, namely directly and indirectly. The direct mechanism occurs through the absorption of dissolved heavy metals by organisms along with the absorption of water and nutrients into the body. In addition, heavy metal mercury can also enter indirectly through the food chain.

Nonessential metals (including heavy metals) will be detoxified by a mussels by synthesizing a protein called metallitionein [19] [20] [21]. Pilsbryoconcha spp has the ability to bioaccumulate in absorbing mercury in polluted water, mussels also have limits on tolerance and endurance when in a polluted environment. This shows that mussel have limits on tolerance to mercury and limits to survival, and that exposure to heavy metal mercury in the water can decrease the growth rate and reduce the weight of mussel, especially when exposed to mercury for a long time can cause death of mussel.

\section{CONCLUSION}

1. There is an effect of mercury concentration on the growth of Pilsbryoconcha spp

2. The growth rate of Pilsbryoconcha spp produced was different, between the mercury concentration of 0 ppm (PO treatment) and $0.5 \mathrm{ppm}(\mathrm{P} 1)$ was not significantly different, but was significantly different from the growth rate of shellfish at the mercury concentration of $1 \mathrm{ppm}$.

\section{REFERENCES}

[1] Hamidah, A. 2012. Pengaruh penggunaan berbagai jenis ikan sebagai inang terhadap kelangsungan hidup glochidia kijing taiwan (Anodonta woodiana Lea). Biota: Jurnal Ilmiah Ilmu-Ilmu Hayati, 11(3), 185-189

[2] Hamidah, A. 2013. Pengaruh Beberapa Ukuran dan Jenis Ikan sebagai Inang Terhadap Densitas Penempelan Glokidia Kijing Taiwan (Anodonta woodiana Lea). Biospecies, 6(2).

[3] Badan Pusat Lingkungan Hidup Daerah Provinsi Jambi (BPLHD). 2015. Status Lingkungan Hidup Daerah Provinsi Jambi 2015. Kota Jambi: Pemerintahan Provinsi Jambi.

[4] Agung, L.N., Hutamadi, R. (2012). Paparan Merkuri di Daerah Pertambangan Emas Rakyat Cisoka, Kabupaten Lebak, Provinsi Banten: Suatu Tinjauan Geologi Medis. Buletin Sumber Daya Geologi, 7, 133-146

[5] Prasad, M.N.V. (2011). A State-of-the-Art Report on Bioremediation: Its Applications to Contaminated Sites in India. Hyderabad: Ministry of Environment \& Forest Government of India

[6] Prilia, D., Oginawati, K., dan Ariesyady, H. D. 2013. Analysis Of Mercury In Water And Sediment Distribution and Its Bioaccumulation Potential In Fish In The Small Scale Gold Mining Area (Case Study: Ciberang River, Lebak, Banten). Journal of Water Sustainabillity. 3(2): 107-108

[7] Palinussa, E. M., 2010. Pemanfaatan Kijing Taiwan (Anadonta woodiana, Lea) Sebagai Biofilter Pada Sistem Budidaya Ikan Mas. Tesis. Program Pasca Sarjana Institut Pertanian Bogor: Bogor.

[8] Fauziah, A. R., Rahardja, B. S., dan Cahyoko, Y. 2012. Korelasi Ukuran Kerang Darah (Anadara granosa) Dengan Konsentrasi Logam Berat Merkuri (Hg) Di Muara Sungai Ketingan, Sidoarjo, Jawa 
Timur. Journal of Marine and Coastal Science.1(1): 41

[9] Putra, S., Arianto, A., Effendi, E., Hasani, Q., dan Yulianto, H. 2016. Efektifitas Kijing Air Tawar (Pilsbryoconcha exilis) Sebagai Biofilter Dalam Sistem Resirkulasi Terhadap Laju Penyerapan Amoniak Dan Pertumbuhan Ikan Lele Sangkuriang (Clarias gariepinus). e-Jurnal Rekayasa dan Teknologi Budidaya Perairan. Vol 4(2) halaman 499

[10] Diaz, E., 2000. Mercury Pollution at Gold Mining Sites In the Amazon environment. Principles of Environmental Toxicology. University of Idaho. 2

[11] Sudarmaji., Mukono, J., P, Corie I. 2006. Toksikologi Logam Berat B3 dan Dampaknya Terhadap Kesehatan. Jurnal Kesehatan Lingkungan. 2(2):136

[12] Ishak, Nuning, A. 2017. Analisis Risiko Lingkungan Logam Berat Merkuri Sedimen Laut Di Wilayah Pesisir Kota Makasar. Jurnal Kesehatan Masyarakat. 7(2): 89

[13] Mohiuddin K. M., Zakir, H. M., Otomo, K., Sharmin, S., dan Shikazono, N. 2010. Geochemical distribution of trace metal pollutants in water and sediments of downstream of an urban river. International Journal of Environmental Science and Technology. 7(1): 17-28.

[14] Pratiwi, C.A. dan Ariesyady, H.D. (2012). Analisis Risiko Pencemaran Merkuri Terhadap Kesehatan Manusia yang Mengonsumsi Beras di Sekitar Kegiatan Tambang Emas Tradisional (Studi Kasus: Desa Lebaksitu, Kecamatan Lebak gedong, Kabupaten Lebak, Banten). Jurnal Teknik Lingkungan, 18, 106-114

[15] Nugroho, A. E. 2006. Tingkat Biofiltrasi Kijing Air Tawar (Pilsbryoconcha exilis) Terhadap Bahan Organik. Skripsi. Program Studi MSP. FPIK-IPB. Bogor.

[16] Fitriawan, F. 2010. Analisis Perubahan Mikroanatomi Dan Variasi Pola Pita Isozim Pada Insang Dan Ginjal Kerang Air Tawar Anodonta woodiana Terhadap Paparan Logam Berat Kadmium. Tesis. Surakarta: Universitas Sebelas Maret.

[17] Puspasari, R. 2006. Logam Dalam Ekosistem Perairan. Jurnal Bawal.1(2): 1-4

[18] Suryono, C, A. 2006. Bioakumulasi Logam Berat Melalui Sistim Jaringan Makanan dan Lingkungan pada Kerang Bulu Anadara inflata. Jurnal Ilmu Kelautan. Vol. 11 (1) : $19-22$.
[19] Lemoine, S., Bigot, Y., Sellos, D., Cosson R.P., and Laulier M. 2000. Metallothionein Isoforms in Mytilus edulis (Mollusca, Bivalvia): Complementary DNA Characterization and Quantification of Expression in Different Organs after Exposure to Cadmium, Zinc, and Copper. Marine Biotechnology. 2: 195

[20] Rahayu, S., Sudrajat, C., Khasyar, Riski, K. 2013. Potensi Kijing Taiwan (Anodonta woodiana) Sebagai Biofilter Merkuri (Hg). Prosiding Seminar Nasional MIPA "Sebagai Landasan Kreasi dan Inovasi Teknologi”. Fakultas MIPA: Universitas Pakuan.

[21] Putranto, T. T. 2011. Pencemaran Logam Berat Merkuri (Hg) pada Air Tanah. Jurnal Teknik. 32 (1) :64-65 